one foels that there are factors controlling the secretion process that have not yet been detected.

The book under review comprises four lectures given in England during the autumn of 1937. In the first two of these the author gives an excellent and very clear exposition of his experiments on the secretion of nitrogen compounds by legumes and of his resulting theory of nitrogen fixation. The third lecture deals with the supposed lack of vitamins in the diet of the Finns. The conclusions to be drawn from the analyses quoted depend on the minimal requirements of average human beings for each vitamin, a point concerning which authorities are not well agreed. The fourth lecturo describes the now well-known A.I.V. process of ensilage, which was developed by the author, who urges that with its help, protein-rich legume fodder can ba preserved with its content of vitamins for winter feed, thus improving the vitamin content of winter milk, to the great benefit of the populace.

The book concludes with a general survey in which the reader is very nearly convinced that the work on investigating nodule secretions on one hand, and the development of the A.I.V. silage process on the other, formed in themselves an example of "associated growth".

H. G. T.

\title{
A STUDY OF DEWPONDS
}

Dewponds in Fable and Fact

By Alfred J. Pugsley. Pp. $x+62+8$ plates. (London : Country Life, Ltd., 1939.) 3s. 6d. net. MR. PUGSLEY describes his little book as 1 "mainly another nail in the coffin of an already dead idea". He goes on to say, however, that "the body won't lie down", which is true enough.

The originator of the belief that certain upland ponds are maintained in times of drought by direct condensation from the atmosphere appears to have been -Gilbert White of Selborne. Letter XXIX in "The Natural History of Selborne" sets out the theory in detail. This simple and, at first sight, attractive idea gained ready acceptanco. It has been demolished scientifically on various occasions; but the writings of the demolishers have never enjoyed a publicity comparable with the writings of Gilbert White. Mr. Pugsley's book contains an adequate summary of the literature, and like other competent investigators he has reached the conclusion that the behaviour of the so-called dewponds is accounted for by the ordinary agencies of rainfall and evaporation. In describing the 'dew' pond idea as "one of the biggest pseudo-scientific swindles that has ever been foisted on unthinking readers of popular periodicals by writers who have not troubled to examine the facts themselves", he can scarcely be accused of over-emphasis.

The word 'dewpond' is, it appears, of relatively recent origin, the earliest reference to the term being in a pamphlet by Rev. H. P. Slade published in 1877. The title-page of Slade's pamphlet, reproduced by Mrr. Pugsley, might lead one to suppose that it was a blatant and valueless exposition of the old dewpond hypothesis. It was, on the contrary, a very thorough study of the factors involved in the maintenance of a pond on the north-east Berkshire Downs, based on accurate observations of rainfall, water-level and consumption by animals. As Slade's work is now almost forgotten, it is of interest to recall that it was noticed and warmly praised by G. J. Symons in his "British Rainfall": Mr. Pugsley also pays tribute to the work of E. A. Martin, who seems to have been the first to demonstrate the fact that the surface temperature of the water in a so-called dewpond scarcely ever falls below the dow-point of the air above it.

Although, in face of the evidence summarized so clearly by the author, the traditional ideas about dewponds must be thrown overboard, there is no doubt at all that they served, and continue to serve, a most useful purpose in areas where surface water supplies are difficult to get. Their construction calls for great skill acquired by long experience, for it must be remembered that the materials naturally available in theso areas do not readily lend themselves to durable water-tight construction, and the power to retain water indefinitely is the essence of the contract. It is a mistake to suppose, however, that there is anything secret or mysterious about the mode of construction. Mr. Pugsley details quite a number of methods. Another myth exploded in the book is that many of the ponds date from neolithic times. He points out that the cleaning process which must be carried out at fairly frequent intervals necessarily involves the removal of some of the puddled material from the bottom of the pond. $\mathrm{He}$ estimates, therefore, that such a pond would not last moro than 100-150 years, unless entirely remade.

The book contains some pleasing photographs of typical dewponds and it may be cordially recommended to those who desire, at trifling cost to themselves, to have at hand a means of clarifying the ideas of their unscientific friends on the subject of dewponds.
E. G. B. 